\title{
Spatial and Temporal Variations of Phytoplankton Communities and Environmental Conditions Along the Coastal Area of Alexandria
}

\author{
Edweb Ali Salem Dango ${ }^{1}$, Mahmoud Salem Ibrahim², Nabila R. Hussein ${ }^{3}$, \\ Maie Ibrahim ElGammal ${ }^{2}$, Mohamed Abel Aziz Okbah ${ }^{3}$ \\ ${ }^{1}$ High Institute in Jerpoly area, Tripoli, Libya \\ ${ }^{2}$ Environmental Science Department, Faculty of Science, Damietta University, Damietta, Egypt \\ ${ }^{3}$ National Institute of Oceanography \& Fisheries, Kayet Bay, Alexandria, Egypt \\ Email address: \\ dwiebi_dango@yahoo.com (E. A. S. Dango),mahmoud salem1912@gmail.com (M. S. Ibrahim), \\ nabila_r_hussein@yahoo.com (N. R. Hussein),mgammal147@du.edu.eg (M. I. El Gmaal), m_okbah@yahoo.com (M. A. A. Okbah)
}

\section{To cite this article:}

Edweb Ali Salem Dango, Mahmoud Salem Ibrahim, Nabila R. Hussein, Maie Ibrahim ElGammal, Mohamed Abel Aziz Okbah. Spatial and Temporal Variations of Phytoplankton Communities and Environmental Conditions Along the Coastal Area of Alexandria. Science Research. Vol. 3, No. 6, 2015, pp. 273-282. doi: 10.11648/j.sr.20150306.12

\begin{abstract}
This paper studied the spatial and temporal variations of phytoplankton communities and environmental conditions. This study focuses on the Spatio-temporal distribution of phytoplankton community structure and environmental conditions (physical conditions, and nutrient availability) along Alexandria coastal area (from Abu Qir in the east to eastern harbor in the west) over one year 2013-2014. The study results gave a signal of the area is light to moderate polluted and emphasized the need of use phytoplankton community as index of water quality. A total of 153 phytoplankton taxa were identified belonging to73 genera (6 Classes); Bacillariophyceae, Dinophyceae, Cyanophyceae, Chlorophyceae, Euglenophyceae and Silicoflagellata. Bacillariophyceae recorded the main bulk, while the others were limited and showed an indication of pollution. The total average density $\left(60.7 \times 10^{3}\right.$ units $\left.\mathrm{l}^{-1}\right)$ was mainly a reflection of the trends in counts of Bacillariophyceae $\left(58.03 \times 10^{3}\right.$ units $\left.1^{-1}\right)$. Species diversity $\left(\mathrm{H}^{\prime}\right)$ ranged between 0.21 and 3.59. The most obvious impact of the previously described physical and chemical features is on the distribution of phytoplankton biomass derived from Chl-a concentration (ranged; $0.92-4.27 \mu \mathrm{gL}^{-1}$ ). The concentrations of the nutrient salts displayed significant seasonal variation. The results revealed that the values of salinity, DO, temperature and $\mathrm{pH}$ were in the ranges: from (35.34 to $38.28 \%$ ), (4.77 and $\left.11.13 \mathrm{mgl}^{-1}\right),\left(18.20\right.$ and $\left.27.5^{\circ} \mathrm{C}\right)$, and $(7.53$ to 8.12$)$, respectively In general, the results indicated that the amounts of ammonia decreased as follows: winter $<$ spring $<$ autumn $<$ summer (ranged; 0.14-5.16 $\mu \mathrm{M}$ ), while nitrate were as follows: spring $<$ autumn $<$ summer $<$ winter (ranged; $3.69-19.66 \mu \mathrm{M}$ ), and the $\mathrm{PO}_{4}-\mathrm{P}$ content were arranged as follows: spring $<$ autumn $<$ winter $<$ summer (ranged; $0.13-0.79 \mu \mathrm{M}$ ).
\end{abstract}

Keywords: Alexandria Coastal Water, Phytoplankton, Diversity Indices, Nutrients, Chlorophyll-a

\section{Introduction}

Alexandria is an Egypt's largest city on the Mediterranean coast, and is one of the most important industrial centers, comprised 100 large factories and about 260 smaller ones [1], to cover about $40 \%$ of the nation's industry. It is also the main summer resort in Egypt; about 4 million citizen and two million summer visitors [2]. The Alexandria coastal zone is about $42 \mathrm{~km}$ long, extending from El-Dekhaila in the west to Abu Qir in the east, and consists of pockets and embayment beaches morphology. Alexandria coastal zone is one of the most important areas along the Egyptian coast of Egypt, including several beaches.

In recent years, there is an appearance of interest in the phytoplankton diversity of the Mediterranean Sea, which is undergoing rapid succession under the pressure of pollution, climate change, ship traffic, introduced species and changes in the distribution of autochthonous species [3]. Research has primarily emphasized the changes in phytoplankton community structure that may have important implications for the entire ecosystem through the food web and 
biogeochemical cycles.

Generally, the water quality was detected and measured by chemical-physical analysis, but in dynamics environment the monitoring using phytoplankton needs to be done, because phytoplankton community analysis will describe clearer figurine the existence of the pollutant impact the community structure in the waters [4,5]. Physico-chemical characteristics and species composition of the phytoplankton community are important indicators of water quality. The differences of phytoplankton distribution and biomass concentrations are expressed in terms of: diversity, relative abundance of species, size class, as well as seasonal succession. Variability of phytoplankton assemblages are explained by several factors; nutrients availability; light variation; and mixing conditions $[6,7]$. The distribution of species within these assemblages is dependent on the degree of stability and nutrient concentrations [8,9]. Nutrient inputs can be of natural origin or anthropogenic origin [10]. In the last decades, numerous investigations have been conducted on the structure and dynamics of phytoplankton communities along the coastal area of Alexandria [11-21]. These earlier studies have helped improve knowledge on the spatiotemporal dynamics of phytoplankton assemblages in coastal area.

This study focuses on the Spatio-temporal distribution of phytoplankton community structure and environmental conditions (physical conditions, and nutrient availability) along Alexandria coastal area (from Abu Qir in the east to eastern harbor in the west) over one year 2013-2014.

\section{Material and Methods}

\subsection{Study Areas}

Ten surface water samples were collected seasonally from the coastal zone of Alexandria using plastic Rottener Sampler of 2 liters capacity. Trips for sampled collection were carried out on a boat. Sampling periods were performed in June, September, December 2013, March and June 2014.Sampling stations were chosen covering the different locations of the costal area (Figure 1).

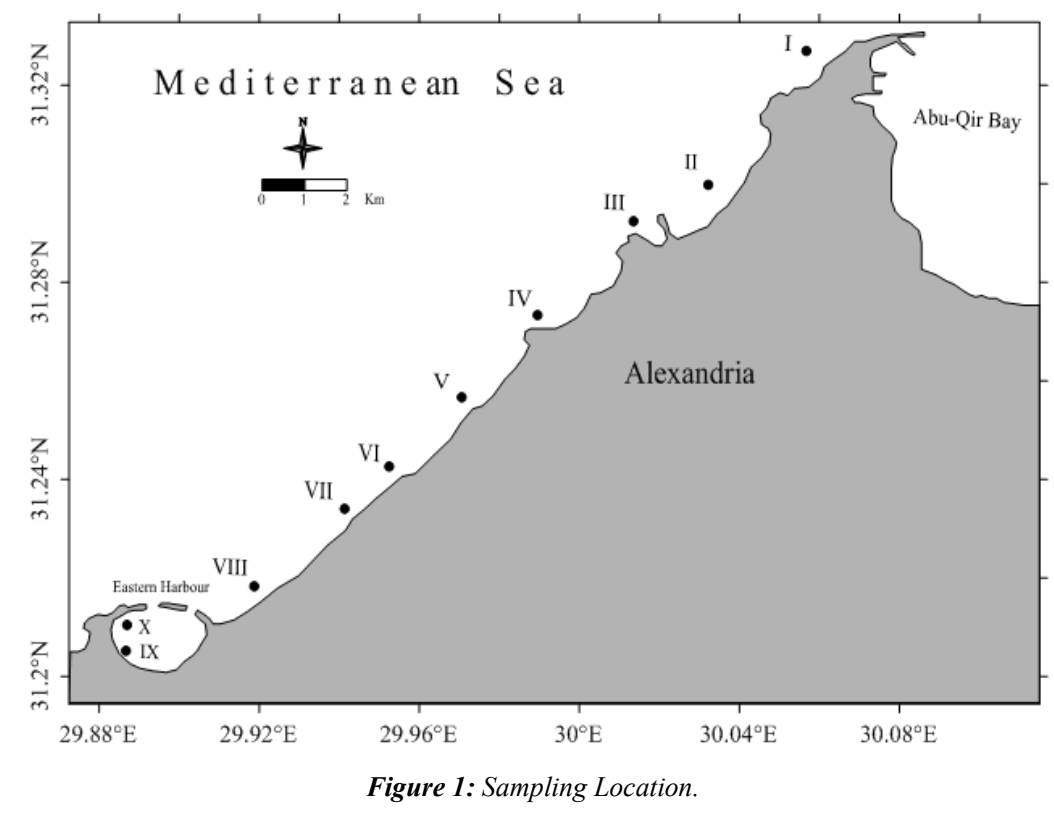

\subsection{Seawater Analysis}

The water temperature was measured with an ordinary thermometer. The $\mathrm{pH}$ value was measured using a pocket $\mathrm{pH}$ meter (model 201/digital pH meter). Water salinity was measured using Bechman salinometer (Model NO. R.S.10). Dissolved oxygen was estimated according to the Winkler method. Samples for nutrient salts were immediately filtered through Whatman GF/C filters and kept frozen until analysis. Samples of ammonium were fixed in the field without filtration.. Dissolved inorganic nitrogen compounds DIN $\left(\mathrm{NH}_{4}-\mathrm{N}, \mathrm{NO}_{2}-\mathrm{N}\right.$ and $\left.\mathrm{NO}_{3}-\mathrm{N}\right)$, reactive phosphate $\left(\mathrm{PO}_{4}-\mathrm{P}\right)$ and reactive silicate $\left(\mathrm{SiO}_{4}\right)$ were determined according to Grasshoff (1976) [22]. Chlorophyll- $a$ in the surface water was extracted with $90 \%$ acetone and measured spectrophotometrically using the SCORE UNESCO [23].
The measurements of dissolved nutrient salts $\left(\mathrm{PO}_{4}-\mathrm{P}, \mathrm{NH}_{4}-\mathrm{N}\right.$, $\mathrm{NO}_{2}-\mathrm{N}, \mathrm{NO}_{3}-\mathrm{N}$ and $\mathrm{SiO}_{4}$ ) and Chlorophyll- $a$ were performed using a Shimadzu double beam spectrophotometer (UV UV150-02), after centrifugation. Absorptions at 630,647,664 and $750 \mathrm{~nm}$ were measured and Chl-a concentration was calculated.

Estimation of the phytoplankton density was carried out by the sedimentation method; the sample was preserved in $4 \%$ neutral formalin. The different species were counted and the results expressed as unit per liter (Cyanobacteria and Chlorophyta contain filament, coenobia and colonies). Various key books and taxt were consulted for identification of phytoplankton species. Diversity $\mathrm{H}^{\prime}$ (Shannon-Wiener index) was used to describe the numerical structure of the phytoplankton community. 


$$
\text { Shannon Index }(H)=-\sum_{i=1}^{S} p i \ln p i
$$

In the Shannon index, $\mathrm{p}$ is the proportion $(\mathrm{n} / \mathrm{N})$ of individuals of one particular species found (n) divided by the total number of individuals found (N), $\ln$ is the natural $\log , \Sigma$ is the sum of the calculations, and $\mathrm{s}$ is the number of species.

\section{Results Discussion}

\subsection{Hydrographic Conditions}

\subsubsection{Physical Parameters}

Water temperature, the values of $\mathrm{pH}$ of the investigated area, and Water salinity were studied, the hydrographic conditions varied widely during the study period (Figures 2, $3,4)$. Water temperature variation was in the range $(18.20$ $27.5{ }^{\circ} \mathrm{C}$ ) (Table1). The values of $\mathrm{pH}$ of the investigated area lie on the alkaline side, its values ranged from 7.53 to 8.19 .
The results of $\mathrm{pH}$ values at most of stations decrease than that normal $\mathrm{pH}$ value of seawater (8.20) observed during June, September 2013 and March 2014 due to wastewater inputs (Table 1). The salinity is an important factor which reflects the changes caused by the mixing of fresh water, drainage water and seawater. The variation of water salinity was recorded in Table1. The lowest value (35.34 PSU) was recorded at station IX, while the highest one (38.28 PSU) was recorded at station VII. The low mean value of salinity recorded in December 2013 and June 2014 (36.01 \pm 0.41 PSU), it was decreased than that reported in the other season. The results are similar to those reported by Fahmy, et al. (1997) [24].

\subsubsection{Chemical Parameters}

The results of DO value varied between 4.77 and 11.13 $\mathrm{mgL}^{-1}$ in the study area (Table1), which the lower value was recorded at station X in June 2014 while the highest value was recorded at station I in December 2013. Generally, the increasing of water temperature leads to the decreasing of DO.

\begin{tabular}{|c|c|c|c|c|c|}
\hline \multirow{3}{*}{ Parameter } & Summer & Autumn & Winter & Spring & Summer \\
\hline & June & September & December & March & June \\
\hline & \multicolumn{3}{|l|}{2013} & \multicolumn{2}{|l|}{2014} \\
\hline $\mathrm{pH}$ & $7.76-8.12$ & $7.75-7.98$ & $7.84-8.19$ & $7.53-7.85$ & $7.66-8.12$ \\
\hline \multirow{2}{*}{ Salinity(PSU) } & $37.68-38.22$ & $37.44-38.28$ & $35.34-36.66$ & $36.00-38.00$ & $35.34-36.66$ \\
\hline & $37.91 \pm 0.52$ & $37.94 \pm 0.31$ & $36.01 \pm 0.43$ & $37.50 \pm 0.53$ & $36.01 \pm 0.43$ \\
\hline \multirow{2}{*}{ Temper. $\left({ }^{\circ} \mathrm{C}\right)$} & $25.20-27.10$ & $26.20-27.50$ & $18.20-20.01$ & $19.80-20.60$ & $23.80-24.30$ \\
\hline & $26.01 \pm 0.65$ & $26.98 \pm 0.45$ & $19.81 \pm 0.57$ & $20.16 \pm 0.35$ & $24.08 \pm 0.19$ \\
\hline DO, mgL-1 & $7.40 \pm 0.81$ & $7.24 \pm 0.76$ & $8.55 \pm 1.54$ & $8.14 \pm 1.40$ & $6.71 \pm 1.37$ \\
\hline \multirow{2}{*}{$\mathrm{NO} 2 / \mathrm{N}(\mu \mathrm{M})$} & $0.07-0.90$ & $0.10-0.96$ & $0.93-1.82$ & $0.01-0.47$ & $0.36-1.22$ \\
\hline & $0.26 \pm 0.26$ & $0.50 \pm 0.27$ & $1.36 \pm 0.24$ & $0.25 \pm 0.15$ & $0.76 \pm 0.25$ \\
\hline \multirow{2}{*}{$\mathrm{NH} 4 / \mathrm{N}(\mu \mathrm{M})$} & $1.51-8.97$ & $1.16-7.55$ & $0.10-0.45$ & $0.27-0.80$ & $0.57-1.34$ \\
\hline & $5.16 \pm 2.36$ & $3.98 \pm 2.19$ & $0.14 \pm 0.11$ & $0.53 \pm 0.16$ & $0.81 \pm 0.11$ \\
\hline \multirow{2}{*}{$\mathrm{NO} 3 / \mathrm{N}(\mu \mathrm{M})$} & $2.50-7.27$ & 2.36-11.99 & $9.04-33.21$ & $2.58-4.64$ & $2.95-11.08$ \\
\hline & $5.03 \pm 1.84$ & $5.79 \pm 3.02$ & $19.66 \pm 7.27$ & $3.69 \pm 0.60$ & $5.67 \pm 3.17$ \\
\hline $\mathrm{PO} 4 / \mathrm{P}(\mu \mathrm{M})$ & $0.29 \pm 0.19$ & $0.25 \pm 0.25$ & $0.40 \pm 0.31$ & $0.13 \pm 0.15$ & $0.79 \pm 0.48$ \\
\hline \multirow{2}{*}{$\mathrm{SiO} 4 / \mathrm{Si}(\mu \mathrm{M})$} & $0.78-26.47$ & $3.88-15.26$ & $11.29-30.43$ & $6.29-30.60$ & $4.57-19.22$ \\
\hline & $10.66 \pm 7.22$ & $7.00 \pm 4.07$ & $20.15 \pm 5.49$ & $13.57 \pm 7.67$ & $10.90 \pm 5.32$ \\
\hline \multirow{2}{*}{ Chl-a( $\mu g l-1)$} & $1.55-4.77$ & $0.38-5.24$ & $0.48-1.76$ & $0.85-4.93$ & $2.22-6.96$ \\
\hline & $3.28 \pm 1.13$ & $2.06 \pm 1.67$ & $0.92 \pm 0.49$ & $2.32 \pm 1.38$ & $4.27 \pm 1.59$ \\
\hline
\end{tabular}

Table 1: Range and Average \pm S. D. of some parameters in Alexandria coastal zone water during 2013-2014.

\subsubsection{Nutrient Salts and Chlorophyll-a (Chl-a)}

Ammonium is the major nitrogenous product of the bacterial decomposition of organic matter containing nitrogen, and is an important excretory product of invertebrates and vertebrates. As for the utilization of nitrogenous materials, ammonium is the preferred inorganic source because of its ease uptake and incorporation into amino acids (N-assimilation). The present study showed that, winter2013, spring and summer 2014 (Table1) have low levels of $\mathrm{NH}_{4} / \mathrm{N}(<1.00 \mu \mathrm{M})$. Faragallah (1995)[25] observed low concentration of $\mathrm{NH}_{4} / \mathrm{N}$ during winter in the eastern harbor $(3.37 \mu \mathrm{M})$ and respect this to promotion of nitrification due to violation of the water as a result of wave and wind action prevailing in this season. Also, Madkour et al. (2007) [26] pointed out that March has the lowest value of
$\mathrm{NH}_{4} / \mathrm{N}$ during 2002. As shown in Figure 3, $\mathrm{NH}_{4} / \mathrm{N}$ concentration in the period of summer and autumn 2013 revealed high levels of $\mathrm{NH}_{4} / \mathrm{N}$ (ranged; $3.98-5.16 \mu \mathrm{M}$ ). Madkour et al. (2007) [26] respect this to the stratification and the effect of the rise in water temperature which may induce the mineralization from the sediment, decomposition rate of sewage and other organic wastes. Nitrate form is generally considered as the most stable and predominant inorganic nitrogen compound in oxygenated sea water. Nitrate concentration ranged between 2.50 and $33.21 \mu \mathrm{M}$. The distribution of $\mathrm{NO}_{3} / \mathrm{N}$ (Figure 3) showed that the concentration during June2013 is similar to that of June 2014. Also the distribution of $\mathrm{NO}_{3} / \mathrm{N}$ through the study period is mostly similar to that of $\mathrm{NH}_{4} / \mathrm{N}$. These refer to the fact that the rate of nitrification is mostly similar to that of denitrification, or due to the oxidation of ammonia to nitrite 
and nitrate either chemically or biologically. The mean concentration of $\mathrm{PO}_{4}-\mathrm{P}$ (Table1) reveled that, the lowest value $(0.01 \mu \mathrm{M})$ was recorded at station II in all seasons except winter (December 2013) and the highest concentration of $\mathrm{PO}_{4} / \mathrm{P}$ in the study area was recorded in summer 2014 $(1.63 \mu \mathrm{M})$ and $(1.37 \mu \mathrm{M})$ at stations VII and $\mathrm{X}$, respectively, Silicate is one of the major constituents in the sea water. It is a good indicator of fresh water dispersion and of the potential for diatom [27].
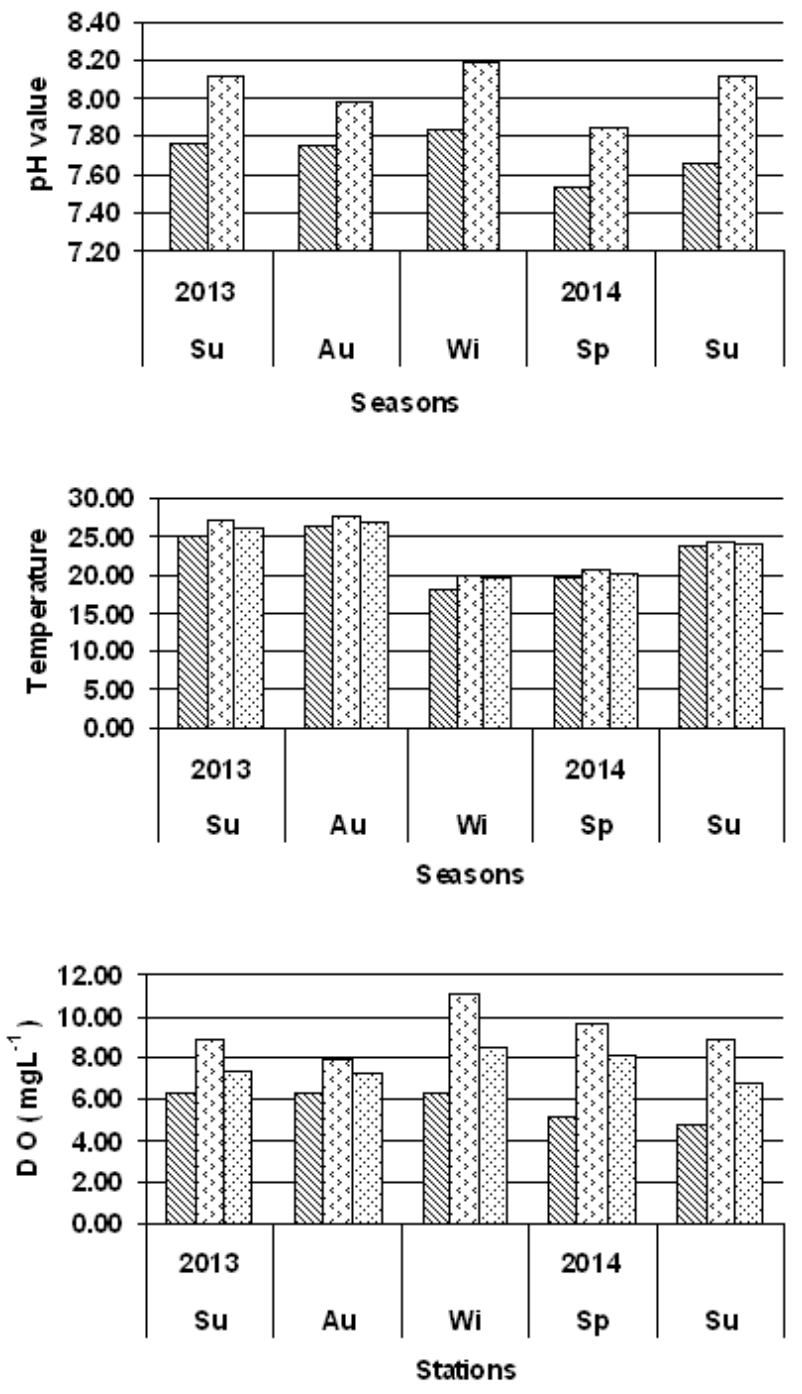

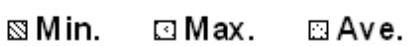

Figure 2: Seasonal variations of $p H$ values, Temperature and DO along the Coastal Area of Alexandria (2013-2014).

The seasonal distribution of silicate concentration in the area of study water showed a wide range of variation (Table1). It ranged from $0.78 \mu \mathrm{M}$ in June 2013 (station IV) to $30.43 \mu \mathrm{M}$ in December (StationVIII). The highest mean content of silicate was found in winter $2014(20.15 \pm 5.49$ $\mu \mathrm{M})$ and decreases to lowest level in autumn $(7.00 \pm 4.07$ $\mu \mathrm{M})$. The lower silicate was recorded during summer, autumn, spring 2013 and summer 2014 (Figure 4); this may be due to the high level of phytoplankton growth (Chl-a was
$3.28 \pm 1.13 ; 4.27 \pm 1.59 \mu \mathrm{g} \mathrm{l}^{-1}$ in summer 2013 and 2014 and $2.06 \pm 1.67 \mu \mathrm{g} \mathrm{l}^{-1}$ in spring 2014, respectively). The present results are the opposite than that reported by Faragallah et al. (2009) [25] in the eastern harbor. The data was similar to those recorded by Dorgham et al. (2004) [28] (9.03 $\mu \mathrm{M})$, in the western Harbor, and it was markedly lower to that reported by Abdel Aziz et al. (2001) [29] (16.74 $\mu \mathrm{M})$ in Abu Qir bay and $49.52 \mu \mathrm{M}$ in El-Dekhaila harbor [30]. Although the drainage waters have been reported as the principal source of silicate in the area and play a significant part in its spatial and temporal distribution, it was found that phytoplankton growth was actually regulating the silicate level [28]. The results showed relationship between phytoplankton and silicate content, this is confirmed with the negative correlation between silicate and Chl-a concentration $(\mathrm{r}=-0.342)$. The same observation was found by Abdel-Halim and Khairy (2007) [31]. The regional variations of silicate content were related to the amounts of drainage water discharged.

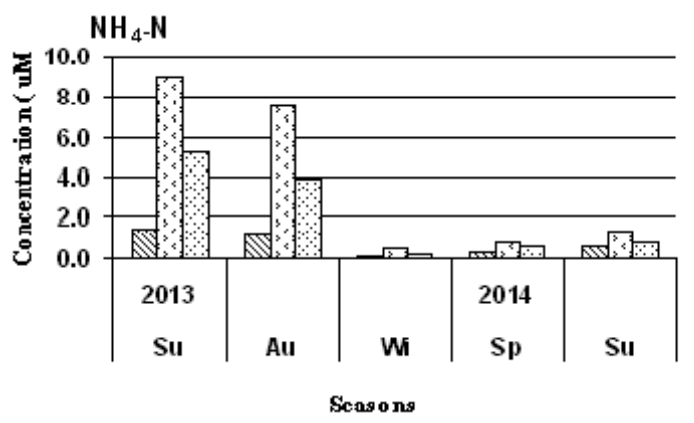

N02-N
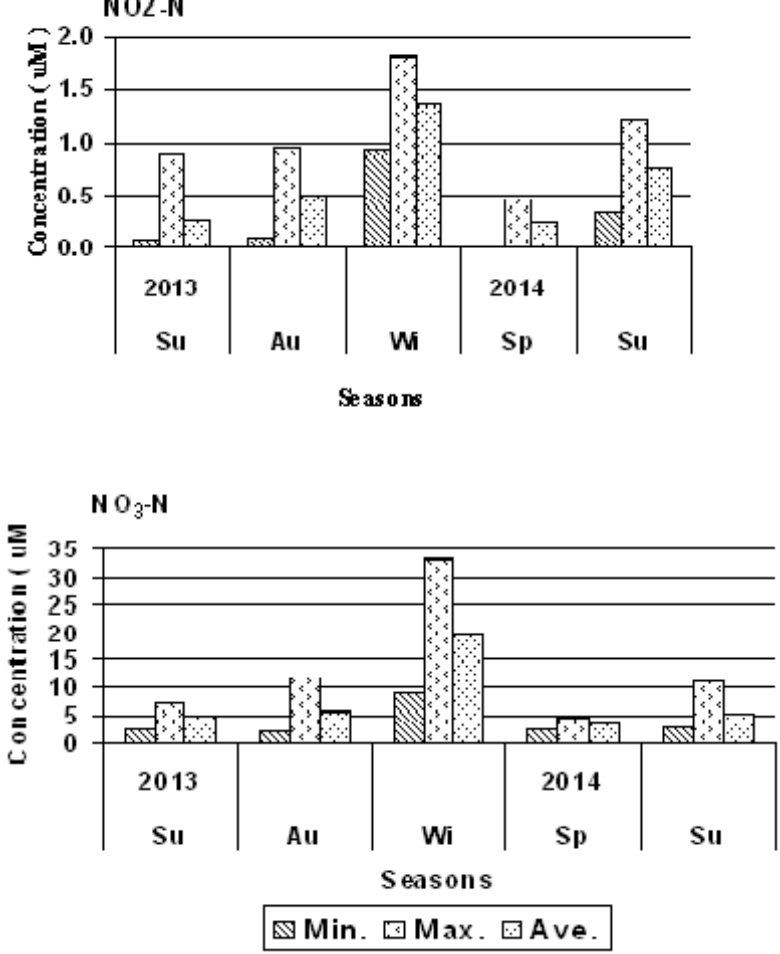

Figure 3: Seasonal variations of Ammonium $\left(\mathrm{NH}_{4}-\mathrm{N}\right)$, Nitrite $\left(\mathrm{NO}_{2}-\mathrm{N}\right)$ and Nitrate $\left(\mathrm{NO}_{3}-\mathrm{N}\right)$ along the Coastal Area of Alexandria (2013-2014) Su: Summer Au: Autumn Wi: Winter Sp: Spring. 

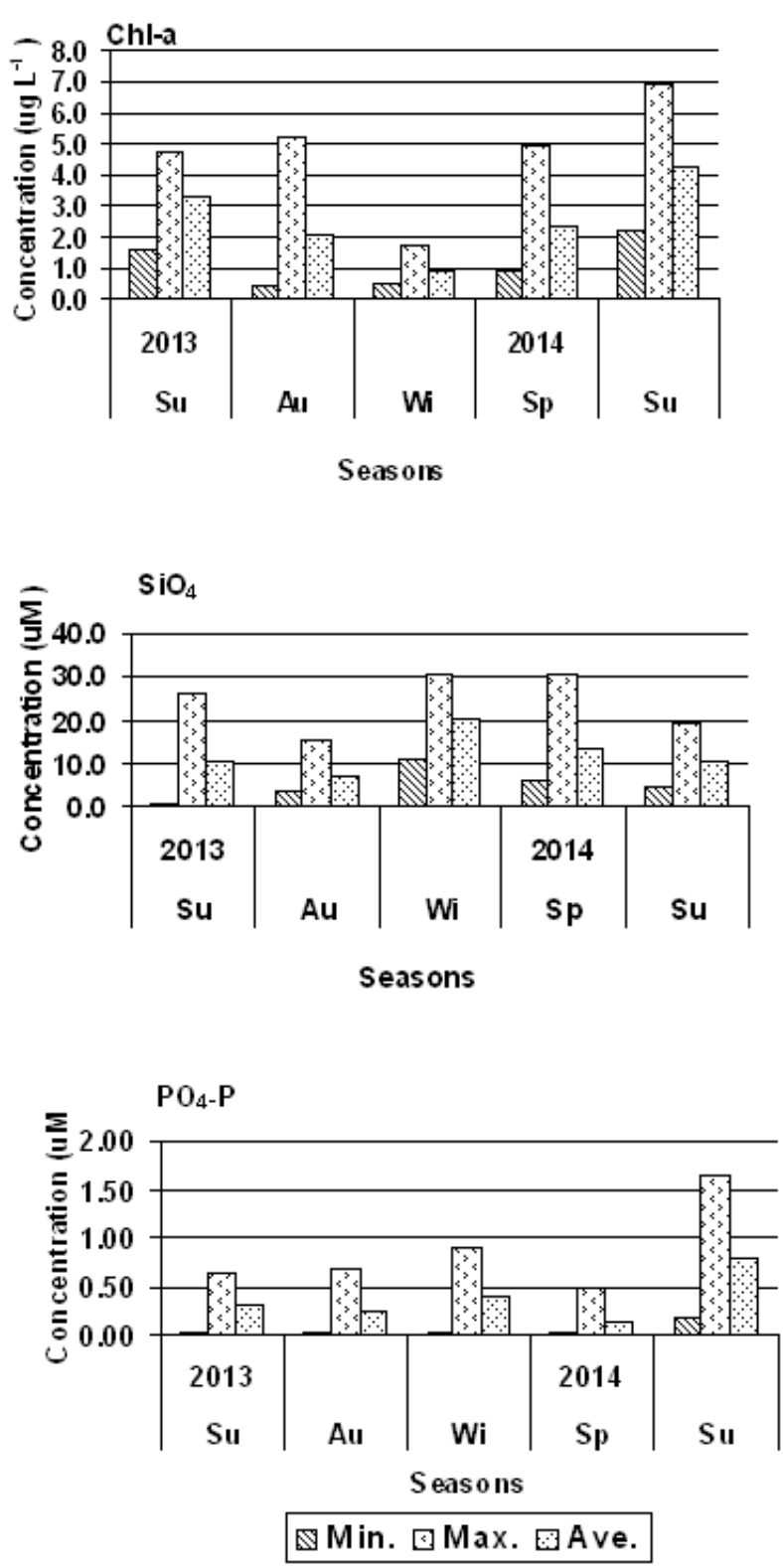

Figure 4: Seasonal variations of Chlorophyll-a (Chl-a), Silicate $\left(\mathrm{SiO}_{4}\right)$ and $\mathrm{PO}_{4}-\mathrm{P}$ along the Coastal Area of Alexandria (2013-2014) Su: Summer Au: Autumn Wi: Winter Sp: Spring.

Chlorophyll-a concentration is considered as a good indicator of the phytoplankton biomass [27], it is used as a trophic state indicator. The mean concentration of Chl-a (Figure 4) was exhibited lower value in autumn $2013(0.38$ $\left.\mu \mathrm{g} \mathrm{l}^{-1}\right)$, while the highest value in June 2014(6.96 $\left.\mu \mathrm{g} \mathrm{l}^{-1}\right)$. The results revealed high concentration of Chl-a in hot seasons. Faragallah et al. (2009) [25] showed that most days during autumn and winter mainly had levels of Chl-a lower than that recoded during spring and summer. The present data of Chl-a was in agreement with that of phytoplankton biomass collected from the same sites [33]. Also, the results indicated relatively high concentration of Chl-a in Alexandria coastal zone comparing with that reported by Ignatiades et al. (1992)[34] in the north and eastern Mediterranean sea (0.01$0.15 \mu \mathrm{g} \mathrm{l}^{-1}$ ) and higher than that recorded in Aegean Sea;
$0.10-0.80 \mu \mathrm{g} \mathrm{l}^{-1}[23]$.

\subsection{Biological Parameters}

\subsubsection{Phytoplankton Community}

The Phytoplankton community in the investigated area during the period of this work was not only productive but also diversified. A total of 153 phytoplankton taxa were identified belonging to 73 genera represented by six groups (Table 2). In previous studied 135 taxa recorded at some coastal area of Alexandria [19], in this study, Bacillariophyceae comprised the highest abundance $(97.46 \%)$ to the total counts represented by 85 species belonging to 44 genera, while Dinophyceae $1.37 \%$ comprised 31 species,. an average value attained about $838.6 \times 10^{3}$ unit $1^{-1}$ [19] (Hussein 2000); a total of 92 taxa were identified at the some coastal area of Alexandria [20]; and a total of 162 phytoplankton species were identified in the EH and 110 species in the KB, [21].

In this work Bacillariophyceae comprised the highest number of taxa, (94 species belonging to 40 genera), with relative frequency $95.55 \%$ of the total numerical abundance (Table3). Dinophyceae contributing about $3.04 \%$ of the total counts (34 species, 12 genera), while Euglenophyceae, Cyanobacteria, Chlorophyceae, Silicoflagellata were rarely recorded contributing all together about $1.41 \%$ to the total counts (Table 3). The Phytoplankton counts attained an average value a bout $\left(60.7 \times 10^{3}\right.$ of unit $\left.1^{-1}\right)$, which is lower than that recorded previously $\left(236.4 \times 10^{3}\right.$ unit $\left.1^{-1}\right)$ [35]; and lower than that recorded at the some coastal area of

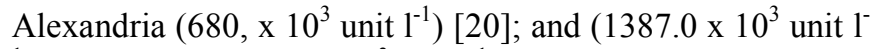
$\left.{ }^{1}\right)$ in the EH and $\left(108 \times 10^{3}\right.$ unit $\left.^{-1}\right)$ in the KB [21].

The highest numerical abundance of phytoplankton appeared during Autumn $2013\left(227.3 \times 10^{3}\right.$ unit $\left.1^{-1}\right)$ and Spring $2014\left(37.5 \times 10^{3}\right.$ unit $\left.1^{-1}\right)$ represented by Six groups most of them belonging to class Bacillariophceae (Table3), while the lowest one detected during Summer 2014 (8.4 x $10^{3}$ unit $1^{-1}$ ) (Table3). The highest average counts appeared at St.I ( $453.3 \times 10^{3}$ unit $\left.1^{-1}\right)$, where 83 species were identified, while the lowest one appeared at St.VIII $\left(8.6 \times 10^{3}\right.$ unit $\left.1^{-1}\right)$, where 59 species were identified. The phytoplankton numerical abundance ranged between $\left(1.2 \times 10^{3}\right.$ unit $\left.1^{-1}\right)$ of St.VIII, summer 2014 and $2.2 \times 10^{3}$ unit $1^{-1}$ of St.I, autumn (Table 4).

Dinophyceae represented by 34 species and 12 genera, with abundance $3.04 \%$ from the total counts, with an average about $1.8 \times 10^{3}$ unit $1^{-1}$ (Table3). On the other hand, Euglenophyceae, Cyanobacteria, Chlorophyceae and Silicoflagellates were rare or scarce forms. Euglenophyceae represented by 5 species, 4 genera and attained its maximum record $\left(2.1 \times 10^{3}\right.$ cell. $\left.^{-1}\right)$ of St. VII, summer 2013, represented by 2 species belonging to 2 genera. Cyanobacteria represented by 8 species, 5 genera reached its maximum count $\left(1.9 \times 10^{3}\right.$ unit $\left.1^{-1}\right)$ of St.IV, Summer 2014 , it was represented by 2 species belonging to 2 genera, while Chlorophyceae represented by 10 species, 10 genera attained its maximum record $\left(6.4 \times 10^{3}\right.$ unit $\left.1^{-1}\right)$ of St. I, Winter 2013 represented by 4 species belonging to 4 genera (Table3). 
Silicoflagellates was scarcely occurrence and represented by 2 species, and 2 genera which appeared during summer and autumn 2013 at Stations I and II respectively (Table3)

\subsubsection{Distribution and Seasonal Variations of Phytoplankton Abundance}

The abundance and species composition of phytoplankton varied strongly at the successive seasons and between stations in the study area. The average phytoplankton counts reached $\left(60.7 \times 10^{3}\right.$ units..$\left.^{-1}\right)$ long Alexandria coastal water (Table3 and Figure5). They varied widely from $1.2 \times 10^{3}$ unit $1^{-1}$ in summer 2014 (St.VIII) to 218.7.2x $10^{3}$ unit $1^{-1}$ in autumn 2013(St.I) (Table 4 and Figure5) as a result of good nutritional conditions caused by continues discharge of allochthonous nutrients and organic load from sewage. Community composition of all stations was dominated by Bacillariophyceae, which constituted the main abundance $(95.55 \%)$ from the total counts. The seasonal variations showed heavy blooms during autumn 2013 at station I, and spring 2014 at station III. Bacillariophyceae reaches (449.3 x $10^{3}$ unit $1^{-1,} 35.9 \times 10^{3}$ unit $1^{-1}$ ), respectively, (Table2). Dinophyceae attained an average $\left(1.85 \times 10^{3}\right.$ unit $\left.\mathrm{l}^{-1}\right)$, with abundance $3.04 \%$ to the total counts Table 3 and Figure 6). The lower values of the phytoplankton counts were observed during summer and winter due to decrease in nutrient, low temperature and light which considerably limited the phytoplankton production.

Table 2: Distribution of Phytoplankton Classes (units $l^{-1}$ ) at all stations along Alexandria Coastal Water (2013-2014).

\begin{tabular}{|c|c|c|c|c|c|c|c|c|c|c|c|c|c|}
\hline Classes & St. I & St. II & St. III & St. IV & St. V & St. VI & St. VII & St. VIII & St. IX & St. $X$ & Total & Aver. & $\%$ \\
\hline Total Bacill & 449340 & 9968 & 35904 & 7022 & 8588 & 11586 & 16104 & 6941 & 17556 & 17302 & 580311 & 58031 & 95.55 \\
\hline Total Chloro & 1420 & 250 & 64 & 132 & 126 & 20 & 120 & 395 & 380 & 180 & 3087 & 309 & 0.52 \\
\hline Total Cyano & 452 & 268 & 230 & 488 & 274 & 280 & 96 & 91 & 220 & 200 & 2599 & 260 & 0.43 \\
\hline Total Dino & 1884 & 5110 & 1936 & 2154 & 1493 & 1552 & 807 & 704 & 1614 & 1226 & 18480 & 1848 & 3.04 \\
\hline Total Eugle & 140 & 110 & 132 & 94 & 302 & 226 & 621 & 509 & 376 & 230 & 2740 & 274 & 0.45 \\
\hline Total Scilico & 20 & 70 & 0 & 0 & 0 & 0 & 0 & 0 & 0 & 0 & 90 & 9 & 0.01 \\
\hline Total phyto & 453256 & 15777 & 38266 & 9890 & 10783 & 13664 & 17748 & 8640 & 20146 & 19138 & 607307 & 60731 & 100 \\
\hline
\end{tabular}

Total Bacillariophyceae: Total Bacill.; Total Chlorophyceae: Total Chloro; Total Cyanobacteria:

Total Cyano; Total Dinophyceae: Total Dino; Total Euglenophyceae; Total Eugle; Total

Scilicoflagellate: Total Scilico; Total phytoplankton: Total phyto

Table 3: Seasonal and Taxonomic composition and proportional representation of the phytoplankton groups (units $l^{-1}$ ) along the coastal area of Alexandria (2013-2014).

\begin{tabular}{|c|c|c|c|c|c|c|c|c|c|}
\hline & Summer & Autumn & Winter & Spring & Summer & annual & & & \\
\hline Phytoplankton groups & & 2013 & & 2014 & & Aver count & Genus & No. of Species & $\%$ \\
\hline Total Bacill & 9539 & 22565 & 14858 & 35906 & 4199 & $58.03 \times 10^{3}$ & 40 & 94 & 95.6 \\
\hline Total Dino & 3023 & 1195 & 536 & 1000 & 3487 & $1.85 \times 10^{3}$ & 12 & 34 & 3.04 \\
\hline Total Chloro & 344 & 178 & 828 & 110 & 84 & $0.31 \times 10^{3}$ & 10 & 10 & 0.52 \\
\hline Total Cyano & 256 & 122 & 289 & 131 & 502 & $0.26 \times 10^{3}$ & 5 & 8 & 0.43 \\
\hline Total Eugle & 477 & 88 & 311 & 360 & 134 & $0.27 \times 10^{3}$ & 4 & 5 & 0.45 \\
\hline Total Scilico & 17 & 28 & 0 & 0 & 0 & $0.01 \times 10^{3}$ & 2 & 2 & 0.01 \\
\hline Total phyto & 13655 & 227264 & 16822 & 37507 & 8406 & $60.7 \times 10^{3}$ & 73 & 153 & 100 \\
\hline
\end{tabular}

Total Bacillariophyceae: Total Bacill; Total Chlorophyceae: Total Chloro; Total

Cyanobacteria: Total Cyano; Total Dinophyceae: Total Dino; Total Euglenophyceae; Total

Eugle; Total Scilicoflagellate: Total Scilico; Total phytoplankton: Total phyto

Table 4: Seasonal variations of the total phytoplankton counts (unit $l^{-1}$ ) at different stations along Alexandria coastal water (2013-2014).

\begin{tabular}{|c|c|c|c|c|c|c|}
\hline \multirow{2}{*}{$\begin{array}{l}\text { Seasons } \\
\text { Stations }\end{array}$} & Summer & Autumn & Winter & Spring & Summer & Average \\
\hline & \multicolumn{3}{|c|}{2013} & \multicolumn{3}{|c|}{2014} \\
\hline I & 13300 & 21872 & 41900 & 13000 & 10880 & 453256 \\
\hline II & 13354 & 17280 & 8650 & 16200 & 23400 & 15777 \\
\hline III & 5070 & 11000 & 18770 & 147700 & 8790 & 38266 \\
\hline IV & 9600 & 6300 & 5110 & 18140 & 10300 & 9890 \\
\hline V & 2695 & 5320 & 11750 & 27310 & 6840 & 10783 \\
\hline VI & 22320 & 5700 & 8500 & 26600 & 5200 & 13664 \\
\hline VII & 3700 & 11700 & 3440 & 62400 & 7500 & 17748 \\
\hline VIII & 22030 & 4850 & 4600 & 10500 & 1219 & 8640 \\
\hline IX & 27040 & 6840 & 32900 & 29220 & 4730 & 20146 \\
\hline$X$ & 17440 & 16450 & 32600 & 24000 & 5200 & 19138 \\
\hline Average & 13655 & 227264 & 16822 & 37507 & 8406 & 60731 \\
\hline
\end{tabular}




\subsubsection{Distribution and Seasonal Occurrence of the Recorded Species}

I. Bacillariophyceae distribution and seasonal variations

The abundance of phytoplankton groups in the present study exhibited clearly different counts in the dominant species. Phytoplankton counts was attained an average value about $\left(60.7 \times 10^{3}\right.$ unit $\left.1^{-1}\right)$, the highest counts recorded during autumn $2013\left(227.3 \times 10^{3}\right.$ unit $\left.^{-1}\right)$ and Spring $2014\left(37.5 \times 10^{3}\right.$ unit $\mathrm{l}^{-1}$ ) represented by Six groups, most of them belonging to class Bacillariophceae, $99.29 \%$, 95.73\% respectively.(Table 4). Bacillariophyceae attained its maximum count at station I during autumn $\left(2187.3 \times 10^{3}\right.$ unit $\left.1^{-1}\right)$, with abundance $99.29 \%$, comprised 69 species, dominated by Thalassiosira rotula meunier $(93.46 \%$ from the total phytoplankton community). On the other hand, the lowest count recorded at St. VIII $\left(0.9 \times 10^{3}\right.$ unit $\left.\mathrm{l}^{-1}\right)$ during summer 2014 as shown in (Figure5).

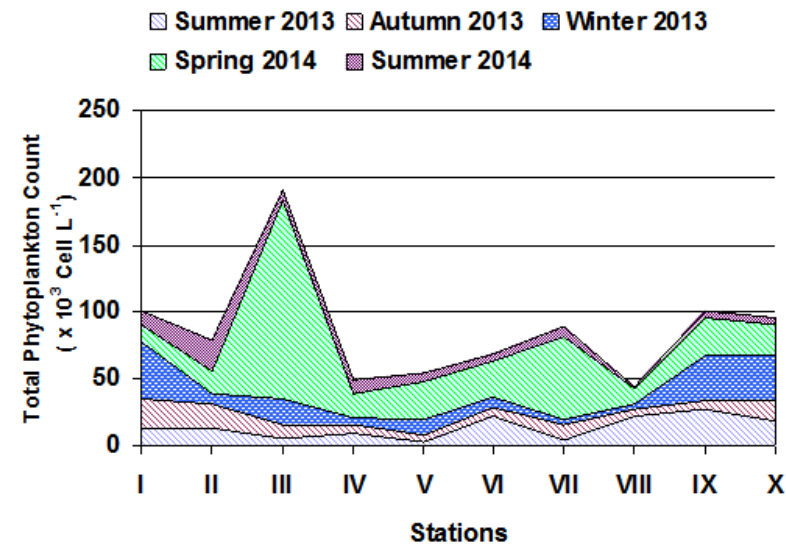

Figure 5: Temporal and Spatial Variation of Total Phytoplankton along Alexandria Coastal Water(2013-2014).

The most dominant diatoms species during the period of this study contributed $49.3 \%$ to the total phytoplankton count in summer 2013, represented by (Skeletonema costatum (Grev.) Cl., Cyclotella meneghiniana Kutz., Grammatophra marina, Leptocylindrus danicus Cleve, Leptocylindrus minimus Grun., Licmophora gracilis, Navicula cryptocephala Kutz, Pseudonitzschia seriata Cleve); and decreased to $33.9 \%$ to the total community in summer 2014, represented by (cocconeis placentula, Cyclotella meneghiniana Kutz., Licmophora gracilis, Melosira granulataV.angustissima Muller, Navicula cryptocephala Kutz, Navicula spectabilis, Nit. longissima, Nit. microcephala Grun, Rhizosolenia delicatula cleve.. The abundance cycle of this group exhibited high level in the cells number of one specie in autumn $2013(93.5 \%)$ to the total phytoplankton count; Thalassiosira rotula Meunier); in winter 2013 represented 64.3\% (Chaetoceros affinii, Coscinodiscus centralis Ehr., Cyclotella meneghiniana Kutz., Melosira granulataV.angustissima Muller, Navicula lanceolata (Agar.)Kutz., Skeletonema costatum (Grev.) Cl., Synedra acus, Synedra ulna(Nitzsch.)Ehr., Thalassiosira rotula Meunier; in spring 2014 were represented $74.2 \%$ by number to the total phytoplankton count (Chaetoceros affinii, Chaetoseros didymus Her., Leptocylindrus danicus cleve., Leptocylindrus minimus Grun., Skeletonema costatum (Grev.)Cl.

II. Dinophyceae distribution and seasonal variations:

While it was considered as rare from planktonic group throughout the Period of investigation, it ranked the second group. It attained an average count $\left(1.85 \times 10^{3}\right.$ unit $\left.1^{-1}\right)$, with abundance $(3.04 \%)$ from the total community (Table3). Dinophyceae was represented by 12 genera including 34 species, attained its maximium count at station II $\left(5.1 \mathrm{x} 10^{3}\right.$ unit $1^{-1}$ ), dominated by Prorocentrum cordatum(Osten.)Abae (0.71\%),Protoperidinium minutium (Kofoid) Balech (0.44 \%), Protoperidinium trochoidium(Stein) Lemm (0.30\%) (4.2x $10^{3}$ unit $1^{-1} ; 2.6 \times 10^{3}$ unit $1^{-1}$ and $1.8 \times 10^{3}$ unit $1^{-1}$ ), during summer season 2013 -2014, respectively. The phytoplankton community was more diverse in Alexandria coastal area (153 species), however, the species composition revealed irregular distribution between the sampling stations along the study area (Table 2 and Figure 6). Bacillariophyceae and Dinophyceae groups appeared to be the major phytoplankton groups; its relative percentage ranged from 49.9 (summer 2014) to $99.3 \%$ (autumn 2013) for Bacillariophyceae and from 0.5 (autumn 2013) to $41.5 \%$ (summer 2014) for Dinophyceae to the total phytoplankton community, the two groups represented 94 species and 34 species, respectively. On the other hand, freshwater represented mainly by Chlorophyceae (10 species), Cyanophyceae (8 species) and Euglenophyceae (5 species), the relative percentage to the total phytoplankton community for the three groups ranged from 1.0 to $4.9 \%$ for Chlorophyceae; from 0.05 to $6.0 \%$ for Cyanophyceae and from 0.04 to $3.5 \%$ for Euglenophyceae. The freshwater taxa showed almost low count, constituting collectively $0.53 \%$ of total phytoplankton in spring 2014 and reached to $2.86 \%$ in summer 2014 .

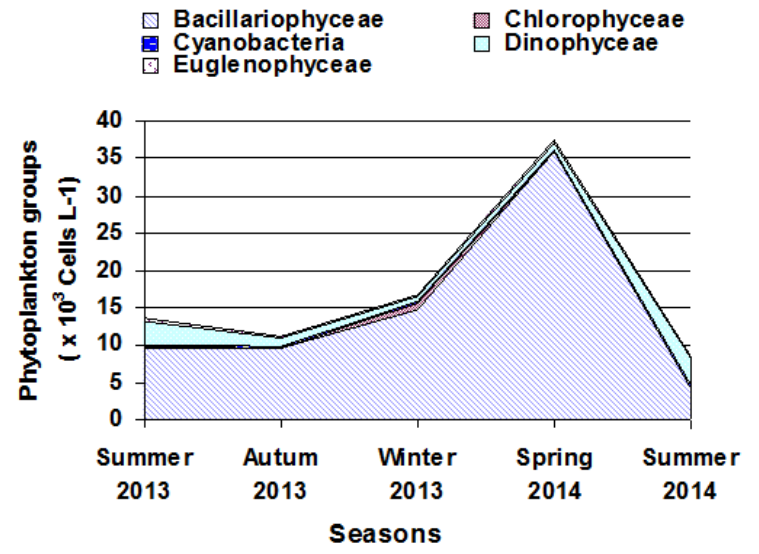

Figure 6: Seasonal distribution of phytoplankton groups along Alexandria coastal area (2013-2014).

\subsubsection{Species Diversity: Diversity Index of Phytoplankton Community}

Diversity index usually illustrates the distribution of the different species within the community. It reflects the pollution status of aquatic habitats, Species diversity is reliable parameter in biology to determine how healthy an environment [36].There are several numerical attempts to 
express degrees of oligotrophy and eutrophy from a consideration of species complements rather than from nutrient levels [37]. In this investigation the species diversity of the phytoplankton was estimated according to the equation of Shannon and Weaver (1963) [38]. The estimated diversity reflects an inverse relationship to the degree of dominance of the main species recorded rather than to the number of species or the magnitude of the phytoplankton counts. In the present study, the diversity index were relatively high most of the time fluctuated between 0.21 and 3.59 (Table5). The abundance and species composition of phytoplankton varied strongly at the successive months and between stations in the study area (Table5), it ranged between a minimum (St.III) $0.21(\mathrm{H})$ in Autumn season 2013 with the dominance of Thalassiosira rotula (97\%) to total phytoplankton counts, accompanied by a higher phytoplankton counts $\left(60.7 \times 10^{3}\right.$ unit..$^{-1}$ ) and a maximum of (St.II) $3.59(\mathrm{H})$ in Autumn season; with the dominance of 3 species namely Skeletonema costatuom (41 \%) in Summer 2013 and Spring 2014 and leptocylindrus minimus (35 \%) in Spring 2014 and Chaetoceros affinii (42\%) in Spring 2014 (The annual average was $2.16 \%$ ), it ranged between a minimum( 0.21$)$ at St.I during Autumn 2013 (30 taxa were recorded) dominated by Thalassiosira rotula (97.11\%) from the total phytoplankton counts,accompanied by a high phytoplankton counts $\left(2187.2 \times 10^{3}\right.$ unit. $\left.^{-1}\right)$, and a maximum of (3.59) at (St.II)during the same season(48 taxa), with the dominance of more than one species, Pseudonitzschia seriata Cleve 6.77\%, Navicula cryptocephala Kutz.6.25\%, Leptocylindrus danicus Cleve5.72\%, Leptocylindrus minimus Grun5.21\% accompanied by a low phytoplankton counts $\left(17.3 \times 10^{3}\right.$ unit $\left.1^{-1}\right)$ Also the diversity index showed low value at St.III $(0.83)$ during winter, where 15 taxa were recorded dominated by Navicula lanceolata (Agar.) Kutz 83.11\%, and phytoplankton counts reached $18.8 \times 10^{3}$ unit $1^{-1}$.

Table 5: Seasonal Variations of Phvtoplankton Diversity at different stations along Alexandria Coastal water (2013-2014).

\begin{tabular}{lllllll}
\hline St. & Summer & Autumn & winter & Spring & Summer & average \\
\hline & $\mathbf{2 0 1 3}$ & & & $\mathbf{2 0 1 2} \mathbf{2 0 1 4 4}$ & & \\
\hline I & 2.43 & 0.21 & -2.79 & 2.25 & 2.87 & 0.99 \\
II & 2.97 & 3.59 & 2.23 & 2.17 & 2.18 & 2.63 \\
III & 2.72 & -3.42 & 0.83 & 2.06 & 2.47 & 0.93 \\
IV & 3.35 & 3.15 & 2.51 & 2.67 & 2.43 & 2.82 \\
V & 2.5 & 3.02 & -2.56 & 2.56 & 2.77 & 1.66 \\
VI & 2.71 & 2.4 & -2.13 & 1.73 & 2.24 & 1.39 \\
VII & 1.6 & 2.74 & 2.3 & 1.43 & 2.39 & 2.09 \\
VIII & 2.6 & 3.09 & 2.4 & 1.5 & 2.01 & 2.31 \\
IX & 3.07 & 2.67 & 2.31 & 2.57 & 2.01 & 2.53 \\
X & 2.23 & 3.42 & 2.55 & 1.47 & 2.72 & 3.91 \\
Average & 2.64 & 2.08 & 0.77 & 2.75 & 2.41 & 2.13 \\
\hline
\end{tabular}

\subsection{Statistical Analysis}

Correlation coefficient of phytoplankton counts, its main groups and physicochemical properties of Alexandria seawater showed that; the data revealed high positive correlation between temperature and total Dinophyceae content $\left(\mathrm{R}^{2}=\right.$ 0.66).This reflects the important role of temperature in the activity of Dinophyceae growth. Total Chlorophyceae group was highly positive correlated with dissolved silicate concentration $\left(\mathrm{R}^{2}=0.90\right)$, also the total Bacillariophyceae showed highly positive correlated with dissolved silicate $\left(\mathrm{R}^{2}=\right.$ $0.95 \mathrm{n}=50, P<0.05)$. The total phytoplankton and dissolved silicate content revealed good relationship $\left(\mathrm{R}^{2}=0.95 \mathrm{n}=50, P<\right.$ 0.05). The two most common parameters used to recognize the composition of wastewater are the biochemical oxygen demand (BOD) and the chemical oxygen demand (COD). BOD5 is a measure of how much dissolved oxygen is consumed by aerobic bacteria in 5 days at $20^{\circ} \mathrm{C}$. It is the broad measure of the strength of the organic matter in a waste stream, the relationship between the BOD and COD was high $(\mathrm{r}=0.72)$. The type of wastewater discharge can be determined according to BOD/ COM (ECPH, 1975). 1: 1 ratio reveals well-purified water; the biodegradable matter has a ratio $\leq 2$ : 1 . Finally the ratio that ranged between $2: 1$ and $4: 1$ is specific to crude domestic sewage. The ratio of $\mathrm{BOD} / \mathrm{COM}$ in the investigated area is less than one during the period of study, ranged from 0.15 to 0.81 . Temperature can affect ammonia toxicity to aquatic species, as well, and $\mathrm{pKa}$ is a function of temperature. As temperature increases, the $\mathrm{pKa}$ value will increase, resulting in an increased percentage of un-ionized ammonia, the data showed high positive correlation between temperature and ammonia $\left(\mathrm{R}^{2}=0.72 \mathrm{n}=50, P<0.05\right)$. Nitrate and nitrite values showed a good relation between them through the study period, this observation may be reflecting the distribution similarity for the two forms $\left(\mathrm{R}^{2}=0.59 \mathrm{n}=50, P<0.05\right)$.

\section{Conclusion}

The continuous land run off into the Mediterranean coast caused massive development of algal blooms and the coastal current allows such blooms to extend along the shore line, and so water quality creates on the long run nuisance and aesthetic problems in the recreational beaches. The results can be concluded as the following:

- Euglenophyceae, Cyanobacteria, Chlorophyceae and Silicoflagellates were rare or scarce forms.

- The data revealed high positive correlation between 
temperature and total Dinophyceae content (R2= 0.66).This reflects the important role of temperature in the activity of Dinophyceae growth.

- Total Chlorophyceae group was highly positive correlated with dissolved silicate concentration (R2= $0.90)$, also the total Bacillariophyceae showed highly positive correlated with dissolved silicate $(\mathrm{R} 2=0.95$ $\mathrm{n}=50, \mathrm{P}<0.05)$.

- The results showed that the highest density of phytoplankton community recorded at Abu-Qir (St.I) (453.3x103units 1-1), while Shatby (St.VIII) showed the lowest density (8.6x103units 1-1).

- The estimated diversity reflects an inverse relationship to the degree of dominance of the main species recorded rather than to the number of species

- A signal of the area is light to moderate polluted and emphasized the need of use phytoplankton community as index of water quality. Accordingly, it is recommended that the waste water should be treated and/ or recycled before discharge into this natural aquatic body.

\section{Acknowledgments}

The authors are thankful to National Institute of Oceanography and Fisheries, Marine Environment Division, Egypt for providing necessary facilities.

\section{References}

[1] Abd-Alla, M. (1993).Concentration of mercury in fresh, brackish and saline water in Alexandria region. M.Sc. Thesis, Institute of Graduate Studies and Research, Alexandria Univ., Egypt, 145 pp.

[2] Nasr, S. M. (1995).Geochemistry and granulometric normalization for heavy metals in the bottom sediments off Alexandria, Egypt. Proceeding of the 2ndConference on the Mediterranean Coastal Environment. MEDCOAST 95, Tarragona, Spain, 1473-1481.

[3] Vadrucci, R. V., Vignes, F. \& Fiocca, A. (2003). Space-time patterns of co-variation of biodiversity and primary production guilds of coastal marine environments. Aquat. Conserv. Mar. Freshw. Ecosyst., 13, 489-506.

[4] Mathivanan, V., P. Vijayan, S., Sabhanayakam \& Jeyachitra, O (2007). An assessment of plankton population of Cauvery river with reference to pollution. J. Environ. Biol., 28, 523526.

[5] Shashi S., T.R., Kiran, B.R., Puttaiah, E.T., Shivaraj, Y. \& Mahadevan, K.M. (2008). Phytoplankton as index of water quality with reference to industrial pollution. J. Environ. Biol., 29, 233-236.

[6] Smayda, T. J. \& Reynolds, C. S. (2001). Community assembly in marine phytoplankton: Application of recent models to harmful dinoflagellates blooms. J. Plankton Res., 23, 447-461.

[7] Marie, G., Barbara K., Anne, G., Amandine, C., Jean, H. H., Sylvia, A. B. M., Pierre L. \& Vanina P. (2014). Contrasting Patterns of Phytoplankton Assemblages in Two Coastal
Ecosystems in Relation to Environmental Factors (Corsica, NW Mediterranean Sea) Diversity, 6, 296-322.

[8] Pinazo, C., Marsaleix, P., Millet, B., Estournel, C., Kondrachoff, V. \& Vehil, R. (2001). Phytoplankton variability in summer in the Northwestern Mediterranean: Modelling of the wind and freshwater impacts. J. Coast. Res., 17, 146-161.

[9] Spatharis, S., Tsirtsis, G., Danielidis, D. B., Do Chi, T. \& Mouillot, D. (2007). Effects of pulsed nutrient inputs on phytoplankton assemblage structure and blooms in an enclosed coastal area. Est. Coast. Shelf Sci., 73, 807-815.

[10] Edweb A. S. D.; Ibrahim M. S.; Okbah M. A. \& El Gmaal M. I. (2015). Distribution and Seasonal Variation of Nutrient Salts and Chlorophyll-a in Surface Seawater along Alexandria Costal Zone Area. Science Research, 3(4): 180-190.

[11] Mikhail S. K. (2001). Phytoplankton variability in the Eastern Harbour of Alexandria during 2000, Bull. Natl. Oceanogr. Fish, A. R. E., 27, 32-52.

[12] El-Sherif Z. \& Mikhail S. K. (2003). Phytoplankton dynamics in the southwestern part of Abu Qir Bay, Alexandria, Egypt, Egypt. J. Aquat. Biol. Fish., 7 (1), 219-239.

[13] Mikhail, S. K. (2003). First occurrence of some Alexandrium, Chattonella, Gymnodinium and Prorocentrum Species in Alexandria waters (Egypt). Mar.Life, 1(1-2)11-19.

[14] Ismael A. A. \& Dorgham M. M. (2003). Ecological indices as a tool for assessing pollution in El-Dekhaila Harbour (Alexandria, Egypt), Oceanologia, 45 (1), 121-131.

[15] Dorgham M. M., Abdel-Aziz N. E., Okbah, M. A. (2004). Eutrophication problems in the Western Harbour of Alexandria, Egypt, Oceanologia, 46 (1), 25-44.

[16] Gharib S. M. \& Dorgham M. M. (2006). Eutrophication stress on phytoplankton community in the Western Harbour of Alexandria, Egypt, Int. J. Ocean Oceanogr., 1 (1), 261-273.

[17] Shams El Din N. \& Abdel Halim A. M. (2008). Changes in phytoplankton community structure at three touristic sites at western Alexandria Beach, Egypt. J. Aquat. Biol. Fish., 12 (4), $85-118$.

[18] Gharib S. M., El-Sherif Z. M., Abdel-Halim A. M. \& Radwan A. A. (2011). Phytoplankton and environmental variables as a water quality indicator for the beaches at Matrouh, southeastern Mediterranean Sea, Egypt: an assessment Oceanologia, 53 (3): 819-836.

[19] Hussein, N., R., (2000). Ecological and Physiological Studies on Phytoplankton in some Coastal areas around Alexandria. $\mathrm{Ph}$. D. Thesis, Faculty of Science, Alexandria University, Egypt: 282.

[20] Hussein, N., R., (2008). Ecological indices as a tool for assessment Eutrophication problems in Alexandria's coastal water, Egypt. Egyptian Journal of Aquatic research Vol.34 No.1: 86-107.

[21] Khairy, H. M.; Hussein, N. R.; Faragallah, H. M. \& Dorgham M. (2014). The phytoplankton communities in two eutrophic areas of the Egyptian Mediterranean Coast. Revista de Biología Marina y Oceanografía.Vol.49,2:267-277,agosto.

[22] Grasshoff, K. (1979). Methods of sea water analysis with contributions by T. Almgreen; R. Dowson; M. Ehrhaedt; S.H. Fonselius; B. Josefsson, F. Koroleff, K. Kremling. Aufl. Weinheim. New York Verlag Chemie. 317 pp. 
[23] UNESCO. (1990). Reports and studies, No.34. Review of potentially harmful substances. Nutrients, $40 \mathrm{pp}$.

[24] Fahmy, M. A., Tayel, F. T., \& Shriadah, M. A. (1997). Spatial and seasonal variations of dissolved trace metals in two contaminated basins of the coastal Mediterranean Sea, Alexandria, Egypt. Bulletin. Faculty of Science. Alexandria University, 37, 187-198.

[25] Faragallah, H. M., H. R. Z. Tadros \& M. A. Okbah (2009). Nutrient salts and chlorophyll-a during short term scale in the Eastern Harbor, Alexandria (Egypt). Egyptian Journal of Aquatic Research, 35(3), 243-250.

[26] Madkour, F; Dorgham, M \& Fahmy, M. (2007). Short term scale observations on phytoplankton in the Eastern Harbour of Alexandria, Egypt. Egyptian Journal of Aquatic Research, 33(1):193-209.

[27] Fahmy, M. A., A.I.Beltagi \& Abbas M. M. (1999). Nutrient salts and Chlorophyll-a in the Egyptian Mediterranean coastal waters. MEDCAST 99- EMECS99 Joint conferences, LandOcean Interactions: Managing Castal Ecosystems, 9-13 November, Antalya, Turkey.

[28] Dorgham, M. M., Abdel-Aziz, N. E., El-Deeb, K. Z. \& Okbah, M.A. (2004). Eutrophication problems in the Western Harbor of Alexandria, Egypt. Oceanologia, 46 (1): 25-44.

[29] Abdel Aziz, N. E. M.; Fahmy, M. A. \& Dorgham, M. M. (2001). Hydrography, nutrient levels and plankton abundance in Abu-Qir Bay, Egypt. Mediterranean Marine Science, 2 (2): 13-17.

[30] Abdel Aziz, N. E. M.; Fahmy, M. A. \& Dorgham, M. M. (2006). water quality observations on the Dekhaila Harbour, Alexandria, Egypt. Egyptian Journal of Aquatic Research, 32 (2): $167-182$
[31] Abdel-Halim, A.M. \& Khairy, H.M. (2007). Potential impact of some abiotic parameters on a phytoplankton community in a confined bay of the Eastern Mediterranean sea: eastern Harbor of Alexandria Egypt. Mediterranean Marine Science, Vol. 8/2, 49-64.

[32] Carlson, R. E. (1977). 'Atrophic state index for lakes', Limnology Oceanography 22(2): 361-369.

[33] Mikhail's. K., Aboul Ezz, S. M. \& Okbah, M. A. (2008). Blooms of toxic microalgae and cooccurringciliates, heterotrophic and mixotrophic dianoflagellates in the eastern harbor, Alexandria (Egypt). Egyptian Journal of Aquatic Research, 34(2): 96-113.

[34] Ignatiades, L., Karydis, M. \& Vounatsou, P. (1992). A possible method for evaluating oligotrophy and eutrophication based on nutrient concentration scales. Marine Pollution Bulletin, 24(5): 238-43.

[35] Zaghloul, F. A. (1994). Impact of pollution on phytoplankton in a coastal marine environment. Egypt. Jour. of Aquatic Research, 20(2):205-221.

[36] Ogbeibu, A. E. \& Edutie, L. O. (2002). Impact of brewery effluent on the water Quality and rotifers of Ikpoba River, Southern Nigeria. African Journal of Environmental Pollution \& Health 1 (1), $1-12$.

[37] Sabae, S. Z. \& Rabeh S. A. (2000). Bacterial indices of sewage pollution inlake Qarun, Fayum, Egypt. Egypt J. Aquat. Biol. Fish., 4, 103-116.

[38] Shannon, G. E. \& Weaver, W. (1963). The mathematical theory of communication. Univ. of Illinois press, Urbana, 125. 